\title{
Listening to the Patient's Story: a Qualitative Approach to Pre-gestational Diabetic Pregnancy
}

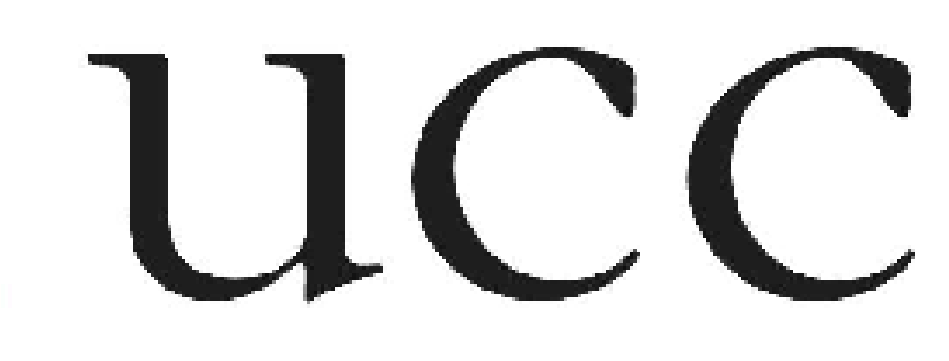

Coláiste na hOllscoile Corcaigh, Éire University College Cork, Ireland

\section{O'Hare CA ${ }^{1}$, Greene $R A^{1,2}$}

1 University College Cork (UCC) School of Medicine, Cork, Ireland ; 2 Department of Obstetrics and Gynaecology, Cork University Maternity Hospital, Cork, Ireland

\section{OBJECTIVES}

-Pregnancy is a crucial challenge for women with diabetes ${ }^{1,2}$

-Pre-gestational diabetics frequently rise to the challenge of pregnancy with remarkable improvements in diabetic control

-Aims of study- to identify self reported:

-supports which drive improvement in diabetes self-care among pregnant women with pre-gestational diabetes

-challenges faced

-motivators

\section{RESULTS}

\section{- Supports perceived to facilitate} self-care:

-Diabetic care team

-Family support

-Working environment

-Maintaining regular daily routine

-Important challenges perceived in pregnancy :

- Maintaining strict diet

- Hypoglycaemia \& turbulent blood glucose

- Emotional challenges

- Glycaemic targets perceived as demanding

- Balancing diabetes care with family and work commitments

-9 of 10 women highly motivated, driven predominantly by concern for baby's wellbeing

- 'SDSCA' questionnaire did not detect significant changes in self-care, yet considerable changes in self-care were reported at interview

\section{METHODS}

-Qualitative research -interviews: 10 pregnant diabetics-6 open-ended questions

-Tertiary referral maternity unit ; number deliveries/year 15, 000

-Convenience sampling; 10 women recruited : ages 20-40 years; median age 33 years

-9 type 1 diabetics; 1 type 2 diabetic

- 6 unplanned pregnancies; 6 primigravida

- Baseline $\mathrm{Hba} 1 \mathrm{c}$ ranged from 42 to $85 \mathrm{mmol} / \mathrm{mol}$, median was $73 \mathrm{mmol} / \mathrm{mol}$. Follow-up measures ranged from $35-53 \mathrm{mmol} / \mathrm{mol}$ median $48 \mathrm{mmol} / \mathrm{mol}$

- Computer assisted qualitative data analysis software (CAQDAS) assisted coding and analysis of interview transcripts

- Content analysis of transcripts was undertaken which revealed numerous themes

- Changes in self-care during pregnancy were measured using a validated questionnaire, 'Summary of Diabetes Self-Care Activities' (SDSCA)

Hba1c $\mathrm{mmol} / \mathrm{mol}$

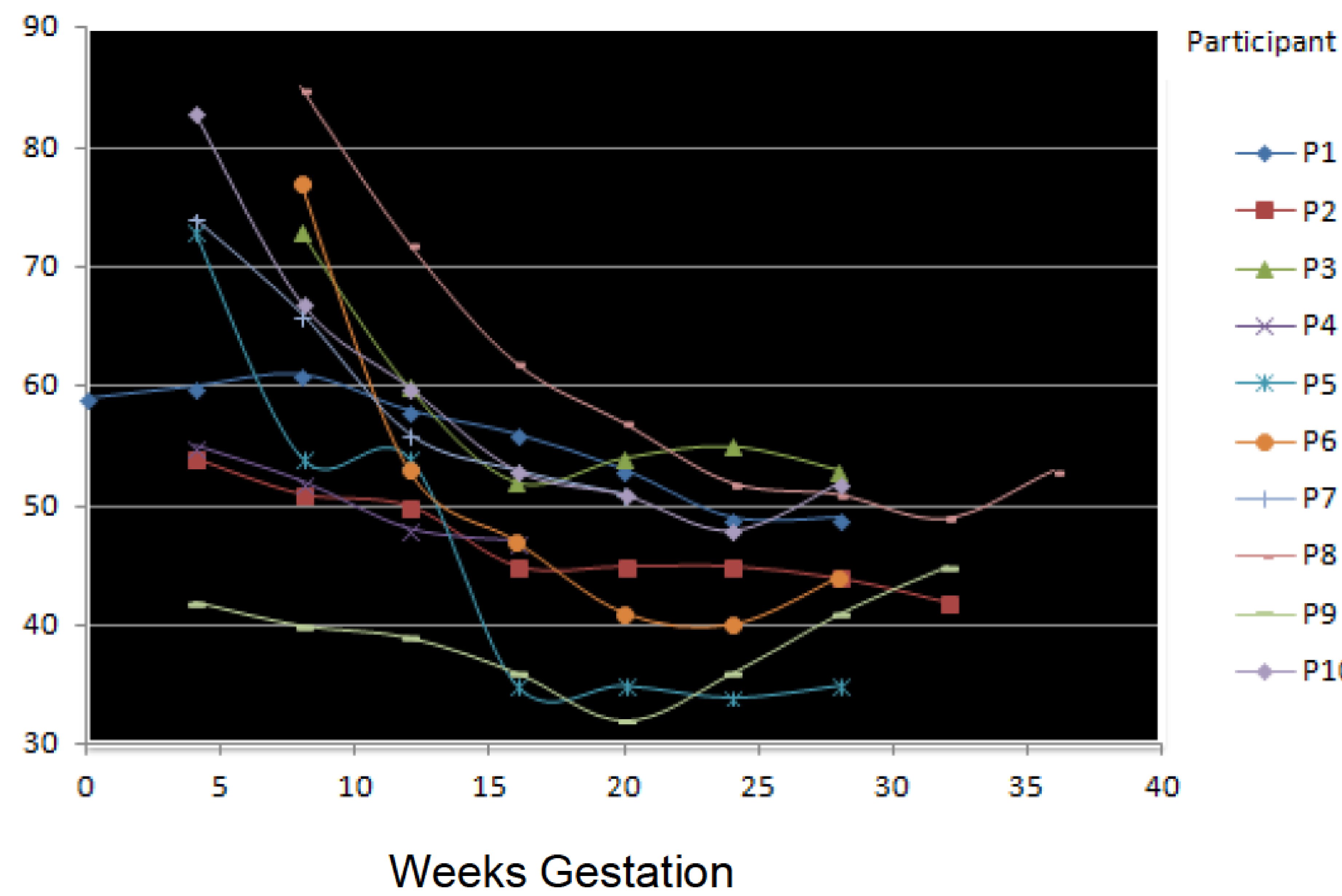

\section{Quotations}

"...being pregnant...it is more like diabetes-life rather than...life and diabetes on the same level... maybe I take it to extreme...but ... if that's what will affect my baby and its development...that's what I have to do" ( P2)

"I'm testing! ...every morning at 3 am ...l've never done that before!" (P8)

"The targets are quite hard...you're always kind of fighting a bit of a battle to keep within targets that you've been given for pregnancy..." (P3)

“...at the start, it was hard with the pregnancy because there were so many new things thrown at $m e "(P 10)$

"...coming into the clinic every 2 weeks...they're good and they help you ... they keep you on the right track...they're always there if you need advice ... they're always very friendly...they're never judgemental...they never put you under pressure..." (P4)

\section{CONCLUSIONS}

\section{References}

1 Evers IN, de Valk HW, Visser GHA. Risk of complications of pregnancy in women with type 1 diabetes: nationwide prospective study in the Netherlands. Brit Med J.2004:328(7445):915-8A. 2 Platt MJ Stanisstreet M, Casson IF Howard CV Walkinshaw Pennycook S, et al. St Vincent's Declaration 10 years on: outcomes of diabetic pregnancies. Diabetic medicine : a journal of the British diabetic pregnancies. Diabetic medicine:

3 Toobert, D. J Hompson, S. E, \& Glasgow, A. R. (2000). The 3 Toobert, D. J., Hampson, S. E., \& Glasgow, A. R. (2000). The studies and a revised scale. Diabetes care, 23(7), 943-950. 